\title{
Use of Coconut Versus Dairy Milk Products in Malaysian Dishes: Comparison of Nutritional Composition and Sensory Evaluation
}

\author{
A. M. Marina*, S. NurulAzizah \\ School of Health Sciences, Health Campus, UniversitiSains Malaysia, 16150 KubangKerian, Kelantan, Malaysia \\ *Corresponding author: mareena@usm.my
}

Received May 07, 2014; Revised May 12, 2014; Accepted May 14, 2014

\begin{abstract}
A study was conducted to determine the nutritional values and sensory evaluation of Malaysian dishes prepared with coconut and dairy milk products. Custard pudding and green curry were cooked using fresh coconut milk (FCM), instant coconut milk (ICM), fresh milk (FM) and evaporated milk (EM). Proximate analysis was carried out following the procedures of AOAC (1996). Sensory evaluation was carried out using 7 point hedonic scale to determine the consumer acceptability of the dishes. The results show that custard pudding prepared using FM had significantly $(\mathrm{P}<0.05)$ lowest fat content $(0.28 \%)$ while the highest protein content was found in EM custard pudding $(2.98 \%)$. The green curry shows similar trend with FM green curry having significantly $(\mathrm{P}<0.05)$ lowest calorie $(0.82 \mathrm{kcal} / \mathrm{g})$ and fat content $(5.68 \%)$ among others. The highest protein content in green curry were found in dishes prepared with dairy products (5.31 - 5.53\%). The sensory evaluation results show that FCM sample was the most appealing in both custard pudding and green curry dishes, as it received significantly highest scores ( $\mathrm{P}$ $<0.05$ ) in all sensory attributes. The Malaysian dishes prepared with dairy milk products were superior in nutritional value compared to dishes made from coconut milk products. However, coconut milk dishes were better accepted than dairy milk dishes, which indicates that consumers are not willing to sacrifice the classic flavor of coconut milk they have used to.
\end{abstract}

Keywords: dairy, coconut milk,green curry, proximate, pudding, sensory

Cite This Article: A. M. Marina, and S. NurulAzizah, "Use of Coconut Versus Dairy Milk Products in Malaysian Dishes: Comparison of Nutritional Composition and Sensory Evaluation.” Journal of Food and Nutrition Research, vol. 2, no. 4 (2014): 204-208. doi: 10.12691/jfnr-2-4-12.

\section{Introduction}

Malaysian traditional dishes represent culinary diversity from multi-ethnic such as Malay, Chinese, Indian and Nyonya. Most traditional foods such as curries and deserts contain coconut milk as the main ingredient. Coconut milk is the liquid obtained by manual or mechanical extraction from the endosperm of coconut. It is widely used in traditional food dishes in Malaysia, Indonesia, Thailand and Philippine [1].

For generations, coconut milk has been used in Malaysian cuisines, not only for the source of thickener but also for the perfect harmonies blend of flavor and aroma. However, other milk such as dairy milk have gained acceptance as a viable way to replace coconut milk in Malaysian dishes. There is a trend among Malaysian to substitute coconut milk with dairy milk in everyday meals because coconut milk is said to be unhealthy for health.

On the contrary, there is also an increase in research of product developments whereby coconut milk is used to substitute dairy milk (cow milk) in dairy products such as cheese [2], yogurt [3], chocolate [4,5] and frozen dessert [6]. This is because dairy milk is originated from animals, whereby coconut milk is originated from plant source, which is perceived to be healthier. In addition, coconut milk would be a better option for vegetarians. Moreover, some people are allergic or have lactose intolerance to dairy milk which limits their dairy products intake [7]. Thus, coconut milk is said to be one of the most suitable replacer for dairy milk.

Dairy milk and coconut milk can serve as substitute for one another, depending on the purpose of substitution. The present study however focused on the nutrient compositions of Malaysian dishes prepared with coconut and dairy milk products. The nutritive value of foods varies with the ingredients and effects of processing [8]. Nowadays, busy lifestyles encourage more usage of convenience foods or ingredients. Instead of using fresh coconut milk, many have opts for commercial carton pack coconut milk or powder coconut milk. For dairy milk users, there is also a choice of using fresh milk, UHT milk or evaporated milk in their dishes. Thus, the type of milk uses influence the nutritive value of the prepared dishes.

Although the proximate composition of coconut milk or dairy milk as a single ingredient is already documented, there is still a need to determine the proximate composition and effect of those milks in a complete meal, since variation from product to product is affected by 
differences in ingredients used. In order to promote the healthy eating campaign, consumers need to know if there is any beneficial health implication of replacing their indispensable ingredients with alternative ingredients. Hence, the present study was undertaken to evaluate two types of Malaysian dishes prepared with different milk sources. This was done in order to document their nutrient compositions and compare their acceptability.

\section{Materials and Methods}

\subsection{Materials}

Fresh coconut milk (FCM) was purchased from local grocery store. Chicken breast was obtained from local wet market. Other ingredients for cooking including carton pack coconut milk or instant coconut milk (ICM), fresh milk (FM) and evaporated milk (EM) were purchased from local hypermarket. All chemicals and solvents used for proximate analysis were of analytical grade.

\subsection{Sample Preparation}

The FCM, FM and EM were used as it is; while ICM was diluted with water at a ratio of $1: 1$ to get the consistency similar to FCM. The recipe for green curry was prepared according to Chef Hanieliza [9]. The ingredients used for green curry were shallot (46 g), garlic (10 g), chilli (14 g), tamarind (4 g), lemon grass (13 g), turmeric powder (3 g), coconut/dairy milk (500 g), ginger (3 g) and chicken breast without skin (250 g). First, shallot, garlic and chillies were blended together. Next, the paste was heated in a pot on a medium heat and slowly stirred until fragrant. Then, chunks of chicken breast, turmeric powder, crushed lemon grass and tamarind were added into the pot. Next, FCM was added and heating was continued until boiling. The procedure was repeated for other formulations by replacing FCM with ICM, FM and EM. The green curry was served hot together with rice as a carrier for sensory evaluation purpose.

The recipe for custard pudding was prepared according to Chef Hanieliza [10]. The ingredients used for custard pudding were custard flour (50 g), sugar (70 g), corns (170 g) and coconut/dairy milk (200 g). First, corns were finely blended. Next, other ingredients including FCM were mixed together with the corns and heated in a medium heat. The pudding was constantly stirred until became glossy. Next, the pudding was transferred into a mould and left to cool. The procedure was repeated for other formulations by replacing FCM with ICM, FM and EM. The pudding was cut into bite sizes before serving to panelists.

\subsection{Proximate Composition Analysis}

The moisture content was determined using air oven method according to AOAC [11]. Crude protein was determined according to semi-micro Kjeldahl method [11]. The fat content was determined by Soxhlet method [11]. The ash content was determined according to AOAC [11]. The percentage of carbohydrate was obtained by subtracting the sum percentage of moisture, crude protein, crude fat and ash from one hundred. The energy content was calculated by multiplying protein, fat and carbohydrate by factors 4, 9 and 4 respectively.

\subsection{Sensory Evaluation}

Sensory evaluation for green curry and custard pudding was carried out using 7 point hedonic scale $(1=$ dislike extremely and $7=$ like extremely) to determine the consumer acceptability of the dishes. A number of 50 untrained panelists consisted of students and staffs of School of Health Sciences, UniversitiSains Malaysia participated. The attributes evaluated for green curry were aroma, color, creaminess, oiliness, flavor and overall acceptance. The attributes evaluated for custard pudding were aroma, color, appearance, creaminess, firmness, flavor and overall acceptance. The mean scores for each attributes were calculated and one way analysis of variance using Duncan test was performed to obtained significant difference among means with $(\mathrm{P}<0.05)$.

\subsection{Statistical Analysis}

All values presented are means of triplicate determination with standard deviations and reported as the mean \pm standard deviation (SD) of the independent trials. Statistical analyses were carried out using One-way ANOVA using SPSS Version 20.0. Significant differences were determined using Duncan's multiple range test with a 95\% significant level $(\mathrm{P}<0.05)$.

\section{Results and Discussion}

\subsection{Proximate Composition}

Table 1. Proximate analysis of custard pudding

\begin{tabular}{|c|c|c|c|c|}
\hline Nutrient & Fresh coconut milk (FCM) & Instant coconut milk (ICM) & Fresh milk (FM) & Evaporated milk (EM) \\
\hline Calorie (Kcal/g) & $2.22 \pm 0.02^{\mathrm{a}}$ & $2.23 \pm 0.05^{\mathrm{a}}$ & $1.51 \pm 0.03^{b}$ & $1.94 \pm 0.03^{c}$ \\
\hline Fat $(\%)$ & $11.61 \pm 0.50^{\mathrm{a}}$ & $8.50 \pm 0.43^{b}$ & $0.28 \pm 0.03^{\mathrm{d}}$ & $2.75 \pm 1.16^{\mathrm{c}}$ \\
\hline Protein (\%) & $0.44 \pm 0.12^{\mathrm{b}}$ & $0.52 \pm 0.27^{\mathrm{b}}$ & $0.58 \pm 0.22^{\mathrm{b}}$ & $2.98 \pm 0.23^{\mathrm{a}}$ \\
\hline Ash (\%) & $0.50 \pm 0.35^{\mathrm{a}}$ & $0.46 \pm 0.39^{\mathrm{a}}$ & $0.61 \pm 0.26^{\mathrm{a}}$ & $0.63 \pm 0.07^{\mathrm{a}}$ \\
\hline Moisture (\%) & $58.62 \pm 0.27^{\mathrm{b}}$ & $54.52 \pm 1.15^{c}$ & $61.88 \pm 0.76^{\mathrm{a}}$ & $54.25 \pm 0.85^{c}$ \\
\hline Carbohydrate & $28.83 \pm 0.65^{c}$ & $36.00 \pm 0.66^{\mathrm{b}}$ & $36.65 \pm 0.59^{b}$ & $39.38 \pm 0.77^{\mathrm{a}}$ \\
\hline
\end{tabular}

*Means with different letters within each row are significantly different $(\mathrm{P}<0.05)$

The result of proximate analysis of custard pudding is shown in Table 1. Custard pudding prepared using FM (1.51 kcal/g) had the lowest calorie content among all samples. This constituted about $32 \%$ reduction of fat from the FM sample $(2.22 \mathrm{kcl} / \mathrm{g})$. Among the dairy puddings, the EM custard pudding $(1.94 \mathrm{kcal} / \mathrm{g})$ contained

significantly higher calorie content than FM sample (1.51 $\mathrm{kcal} / \mathrm{g})$. The concentrated sugar content in EM probably contributed to the higher calorie content. The FCM (2.22 $\mathrm{kcal} / \mathrm{g})$ and ICM (2.23 kcal/g) samples were not significantly different $(\mathrm{P}<0.05)$ and both had the highest calorie contents among all samples. Generally, the energy 
contents in the present study were slightly lower than custard pudding made from soybean flour (3.68 - 3.76 $\mathrm{kcal} / \mathrm{g}$ ) reported by Okoye, Nkwocha \& Agbo [12].

The FCM custard pudding (11.61\%) had significantly $(\mathrm{P}<0.05)$ highest fat content among all samples, which reflected in its being the highest calorie content among all samples. FM custard pudding (0.28\%) scored significantly $(\mathrm{P}<0.05)$ lowest fat content compared to other samples. Generally, the fat contents of custard puddings made from coconut milk products in the present study were higher than those made from dairy milk products. Since the only source of variation in the samples was the fat content, thus it can be concluded that coconut milk contributed more fat than dairy milk in the present study. However, according to To [5], the fat content of coconut milk and whole cow milk was comparable, which was $8 \mathrm{~g}$ of fat per 1 cup. Dawane, Ranveer\& Nagargoje [13] on the other hand found that coconut milk was richer in fat content than dairy (buffalo) milk.

The protein contents in the puddings range from 0.44 to 2.98\% with EM sample having significantly highest $(\mathrm{P}<$ 0.05) protein content compared to other samples. There were no significant differences between FCM, ICM and FM in the protein content. Generally, the protein content in the present study was lower than that published in the Nutrient Composition of Malaysian Foods [14]. This was probably due to the slight difference in recipe and ingredients used in making the custard pudding.

The ash content, which represents the mineral contents in the custard pudding, shows no significant difference in all samples. The moisture content indicates that the pudding made from fresh fat (FCM and FM) had higher moisture level than those made from processed fat (ICM and EM). The moisture contents in this study were generally lower than that reported in custard made from stevia powder [15]. The carbohydrate content was significantly highest $(\mathrm{P}<0.05)$ in the EM sample $(39.38 \%)$ while FCM samples (28.83\%) had the lowest carbohydrate content. The carbohydrate contents in the present study were slightly higher than previously reported for custard pudding [14].

Table 2 shows the proximate composition of green curry. The calorie content of green curry samples ranges from 0.82 to $5.19 \mathrm{kcal} / \mathrm{g}$. The green curry shows similar trend with that of custard pudding in which green curries made from coconut milk products had significantly higher calorie contents than those made from dairy milk products. The highest fat content was found in ICM sample, which was $57.46 \%$, more than twice the amount of fat content in FCM (27.83\%). According to Ng and Tee [16], the fat content of commercially available coconut milk powder was about twice the level of fat content than that of fresh coconut milk. Fat is the major nutrient in coconut and thus serves as the main source of energy [17].

The protein content ranges from 0.37 to $5.53 \%$. The protein contents in dairy milk green curries were significantly higher than those made from coconut milks. Generally the protein contents in the present study were lower than reported for Malay chicken curry in previous study [14] but comparable to 'Murgimansaljol', an Indian chicken curry, reported by Das, Devi \&Gogoi [18]. The ash content was highest in EM green curry (3.84\%) and lowest in FM sample (1.02\%). The ash contents in this study were comparable to ash content in chicken curry of Indian dishes reported by Prasad et al. [19]. The moisture content ranges from 40.52 to $85.66 \%$. The carbohydrate contents in the present study were lower than reported for 'Kaengkarigai', a Thai curry dish [20].

Table 2. Proximate analysis of green curry

\begin{tabular}{ccccc}
\hline Nutrient & Fresh coconut milk (FCM) & Instant coconut milk (ICM) & Fresh milk (FM) & Evaporated milk (EM) \\
\hline Calorie (Kcal/g) & $2.71 \pm 0.04^{\mathrm{b}}$ & $5.19 \pm 0.02^{\mathrm{a}}$ & $0.82 \pm 0.04^{\mathrm{d}}$ & $1.45 \pm 0.01^{\mathrm{c}}$ \\
Fat (\%) & $27.83 \pm 0.30^{\mathrm{b}}$ & $57.46 \pm 0.34^{\mathrm{a}}$ & $5.68 \pm 0.45^{\mathrm{d}}$ & $9.58 \pm 0.48^{\mathrm{c}}$ \\
Protein (\%) & $2.76 \pm 0.36^{\mathrm{b}}$ & $0.37 \pm 0.09^{\mathrm{c}}$ & $5.53 \pm 0.18^{\mathrm{a}}$ & $5.31 \pm 0.38^{\mathrm{a}}$ \\
Ash (\%) & $1.70 \pm 0.25^{\mathrm{b}}$ & $1.55 \pm 0.03^{\mathrm{b}}$ & $1.02 \pm 0.39^{\mathrm{c}}$ & $3.84 \pm 0.27^{\mathrm{a}}$ \\
Moisture (\%) & $65.44 \pm 0.59^{\mathrm{c}}$ & $40.52 \pm 0.22^{\mathrm{d}}$ & $85.66 \pm 0.17^{\mathrm{a}}$ & $71.98 \pm 0.38^{\mathrm{b}}$ \\
Carbohydrate & $2.27 \pm 0.85^{\mathrm{b}}$ & $0.10 \pm 0.14^{\mathrm{c}}$ & $2.11 \pm 0.15^{\mathrm{b}}$ & $9.30 \pm 1.18^{\mathrm{a}}$ \\
\hline
\end{tabular}

*Means with different letters within each row are significantly different $(\mathrm{P}<0.05)$

Table 3. Sensory analysis of custard pudding

\begin{tabular}{|c|c|c|c|c|}
\hline Attribute & Fresh coconut milk (FCM) & Instant coconut milk (ICM) & Fresh milk (FM) & Evaporated milk (EM) \\
\hline Aroma & $6.06 \pm 0.84^{\mathrm{a}}$ & $4.44 \pm 1.30^{\mathrm{b}}$ & $4.46 \pm 1.45^{\mathrm{b}}$ & $4.70 \pm 1.34^{\mathrm{b}}$ \\
\hline Color & $6.06 \pm 0.98^{\mathrm{a}}$ & $3.70 \pm 1.39^{\mathrm{d}}$ & $5.08 \pm 1.09^{b}$ & $4.32 \pm 1.32^{\mathrm{c}}$ \\
\hline Appearance & $5.60 \pm 1.05^{\mathrm{a}}$ & $3.94 \pm 1.02^{\mathrm{c}}$ & $5.10 \pm 1.09^{\mathrm{b}}$ & $4.36 \pm 1.27^{c}$ \\
\hline Creaminess & $5.30 \pm 1.04^{\mathrm{a}}$ & $4.08 \pm 1.52^{\mathrm{b}}$ & $4.36 \pm 1.35^{\mathrm{b}}$ & $4.08 \pm 1.54^{\mathrm{b}}$ \\
\hline Firmness & $5.20 \pm 1.05^{\mathrm{a}}$ & $4.30 \pm 1.36^{\mathrm{b}}$ & $4.48 \pm 1.45^{\mathrm{b}}$ & $4.04 \pm 1.41^{\mathrm{b}}$ \\
\hline Flavor & $5.84 \pm 1.08^{\mathrm{a}}$ & $3.72 \pm 1.54^{c}$ & $4.32 \pm 1.40^{\mathrm{b}}$ & $3.86 \pm 1.37^{\mathrm{bc}}$ \\
\hline Overall acceptance & $5.96 \pm 0.78^{\mathrm{a}}$ & $4.101 .18^{\mathrm{b}}$ & $4.50 \pm 1.09^{c}$ & $4.06 \pm 1.22^{\mathrm{d}}$ \\
\hline
\end{tabular}

*Means with different letters within each row are significantly different $(\mathrm{P}<0.05)$

\subsection{Sensory Evaluation}

The sensory evaluation for custard pudding is given in Table 3. The sensory evaluation results show that custard pudding prepared with FCM was the most appealing compared with others as it received significantly highest scores $(\mathrm{P}<0.05)$ in all sensory attributes namely aroma (6.06), color (6.06), appearance (5.60), creaminess (5.30), firmness (5.20), flavor (5.84) and overall acceptance (5.96). This was probably because FCM imparted unique flavor to the dish. This result was in agreement with
Belewu and Azeez [4] who found that chocolate product prepared with coconut milk was most accepted compared to chocolate milk prepared with cow and goat milk. According to Wattanapahuet al., [21], coconut milk contains various volatile compounds such as delta lactone, n-octanol, dodecanoic acid and decanoic acid which were identified as fresh, creamy, aromatic and nutty aromatic. Those volatile compounds facilitated in enhancing the flavor of coconut milk dishes in the present study.

The custard pudding prepared with ICM however was rated inferior in all of the sensory attributes in comparison with FCM sample. ICM sample scored significantly 
lowest $(\mathrm{P}<0.05)$ in most attributes including overall acceptance among all samples. This probably due to the loss of most of the volatile compounds in coconut milk during storage and thus the ICM lacked the classic flavor and aroma featured in the FCM sample.

Green curry prepared with FCM had significantly highest acceptability $(\mathrm{P}<0.05)$ in all sensory attributes namely aroma (5.22), color (5.68), creaminess (4.90), oiliness (5.12), flavor (5.20) and overall acceptability (5.48) (Table 4). The familiar taste of pure coconut milk in the curry, which panelist have accustomed to, was probably responsible for the highest acceptance of FCM sample. Green curries made with dairy milks were rated significantly lower $(\mathrm{P}<0.05)$ in creaminess, oiliness and flavor in comparison to the green curries made from coconut milk products. Significant difference $(P<0.05)$ exists in aroma, color, flavor and overall acceptance among green curries made with coconut milk products, with FCM sample recorded higher acceptability than ICM sample. FCM sample used fresh while ICM sample used minimally processed coconut milk. This indicates that processing does contribute to lower physical appearance and affects the flavor acceptability in coconut milk products.

Table 4. Sensory analysis of green curry

\begin{tabular}{|c|c|c|c|c|}
\hline Attribute & Fresh coconut milk (FCM) & Instant coconut milk (ICM) & Fresh milk (FM) & Evaporated milk (EM) \\
\hline Aroma & $5.22 \pm 1.06^{\mathrm{a}}$ & $3.86 \pm 1.26^{b}$ & $3.40 \pm 1.25^{b}$ & $3.42 \pm 1.33^{b}$ \\
\hline Color & $5.68 \pm 1.10^{\mathrm{a}}$ & $3.58 \pm 1.30^{c}$ & $4.30 \pm 1.45^{b}$ & $4.44 \pm 1.18^{b}$ \\
\hline Creaminess & $4.90 \pm 1.11^{\mathrm{a}}$ & $4.56 \pm 1.50^{\mathrm{a}}$ & $3.06 \pm 1.19^{\mathrm{b}}$ & $3.48 \pm 1.50^{\mathrm{b}}$ \\
\hline Oiliness & $5.12 \pm 1.32^{\mathrm{a}}$ & $4.88 \pm 1.08^{a}$ & $3.34 \pm 1.42^{b}$ & $3.70 \pm 1.27^{b}$ \\
\hline Flavor & $5.20 \pm 1.11^{a}$ & $4.60 \pm 1.49^{b}$ & $3.12 \pm 1.15^{d}$ & $3.92 \pm 1.55^{\mathrm{c}}$ \\
\hline Overall acceptance & $5.48 \pm 0.86^{\mathrm{a}}$ & $4.40 \pm 1.23^{\mathrm{b}}$ & $3.40 \pm 1.01^{\mathrm{c}}$ & $3.76 \pm 1.35^{\mathrm{c}}$ \\
\hline
\end{tabular}

*Means with different letters within each row are significantly different $(\mathrm{P}<0.05)$

The fatty flavor or the creaminess attribute, the main valued criteria in coconut milk, was not affected between the curry made by fresh and processed coconut milk. This was shown by FCM and ICM samples having no significant difference $(\mathrm{P}<0.05)$ in creaminess and oiliness attributes. Previous studies suggest that perception of taste is largely influence by the fat content [22,23]. Proximate analysis shows that fat contents of coconut milk curries were higher than dairy milk curries in the present study. According to Richardson-Harman et al., [24], there is positive relationship between preference and fat content in assessment of creaminess. This could be the reason why panelists preferred the coconut milk curries over dairy milk curries.

\section{Conclusion}

The Malaysian dishes made from dairy milk products had the highest protein content while being lowest on fat and calorie contents, which indicate that dairy milk dishes are healthier than coconut milk dishes. Replacement of coconut milk with dairy milk in traditional Malaysian dishes can improve the nutritional value of the dishes. Nonetheless, coconut milk dishes especially those prepared using fresh coconut milk scored higher acceptability than dairy milk dishes. This indicates that consumers still prefer the old-style classic flavor of coconut milk in Malaysian dishes. More work should be done to improve the texture and flavor of Malaysian cuisines made with dairy milk in order to increase the acceptability rating of those dishes.

\section{Acknowledgement}

This research was financed by the UniversitiSains Malaysia short term grant (304/PPSK/61311055).

\section{References}

[1] Phattayakorn K, Wanchaitanawong P (2009) Antimicrobial activity of Thai herbs extracts against coconut milk spoilage microorganism. Kasetsart Journal Natural Science 43: 752-759.
[2] Ocancey AK (2010). Development of cheese products from coconut milk. Msc Thesis, Kwame Nkrumah University of Science and Technology, Kumasi, Ghana.

[3] Kolapo AL, Olubamiwa AO (2012) Effect of different concentrations of coconut milk on the chemical sensory properties of soy-coconut milk based yogurt. Food and Public Health 2: 85-91.

[4] Belewu MA, Azeez TA (2008) Coconut chocolate: preparation, compositional and organoleptic qualities. European Journal of Science and Research 22: 144-152.

[5] To EK (2012) Sensory evaluation ratings of non-dairy milk substitute in a cold chocolate dessert. Msc Thesis, D' Youville College, New York.

[6] Soler L (2001) Development of non-dairy frozen dessert containing soy protein and coconut milk. Msc Thesis, Lousiana State University, Baton Rouge.

[7] Crittenden R, Bennet L (2005) Cow's milk allergy: a complex disorder. Journal of the American College Nutrition 24: 582-591.

[8] Premavalli KS, Mazumdar TK, Madhura CV (2001) Processing effect on colour and vitamins of green leafy vegetables. Journal of Food Science and Technology 41: 563- 566.

[9] Chef Hanieliza, Senangnya Memasak: Ayam (ResepiPilihan). BS Print SdnBhd, Kuala Lumpur, 2010.

[10] Chef Hanieliza, Senangnya Memasak: Pudingdan PencuciMulut. BS Print SdnBhd, Kuala Lumpur, 2010.

[11] Asssociation of Official Analytical Chemists (1996) Official Methods of Analysis. $14^{\text {th }}$ Ed, AOAC, Virginia

[12] Okoye JI, Nkwocha AC, Agbo AO (2008) Nutrient composition and acceptability of soy-fortified custard. Continental Journal of Food Science and Technology 2: 37-44.

[13] Dawane DD, Ranveer RC, Nagargoje KD (2010) Utilization of tender coconut (Cocosnucifera L.) milk in the preparation of pudding. Food Science Research Journal 1: 111-115.

[14] Tee ES, Mohd Ismail N, MohdNasir A, Khatijah I, Nutrient composition of Malaysian Foods. $4^{\text {th }} \mathrm{ed}$, Institute of Medical Research, Kuala Lumpur, 1997.

[15] Agarwal V, Kochhar A, Sachdeva R (2010) Sensory and nutritional evaluation of sweet milk products prepared using stevia powder for diabetics. Ethno Medicine 4: 9-13.

[16] Ng TKW, Tee ES (1998) Replacing coconut santan with palm oil santan: impact on dietary C12-16 saturated fatty acids, serum total cholesterol and cardiovascular risk. Malaysian Journal of Nutrition4: 65-72.

[17] Gunathllake KDPP, Bandara AGA (2005) Preparation of a readyto-use coconut cum spices paste for chicken curry and evaluation of its physicochemical and storage properties. Cocos 17: 21-29.

[18] Das O, Devi LP, Gogoi M (2009) Nutrient composition of some regional recipes of Assam, India. Ethno Medicine 3: 111-117.

[19] Prasad NN, Siddalingaswamy M, Parameswariah PM, Radhakrishna K, Rao RV, Viswanathan KR, Santhanan K (2000) Proximate and mineral composition of some processed traditional and popular Indian dishes. Food Chemistry 68: 87-94. 
[20] Tangkanakul P, Auttaviboonkul P, Niyomwit B, Lowvitoon N, Charoenthamawat P, Trakoontivakorn G (2009) Antioxidant capacity, total phenolic content and nutritional composition of Asian foods after thermal processing. International Food Research Journal 16: 571-580.

[21] Wattanapahu S, Suwonsichon T, Jirapakkul W, Kasermsumran S (2012) Categorization of coconut milk products by their sensory characteristics. Kasetsart Journal Natural Science 46: 944-954.

[22] Brewer J, Blake A, Rankin S, Douglass L (1999) Theory of reasoned action predicts milk consumption in women. Clinical Application in Nutrition 2: 39-44.
[23] Bus A, Worsley A (2003) Consumers' sensory and nutritional perceptions of three types of milks. Public Health Nutrition 6: 201-208.

[24] Richardson-Harman NJ, Stevens R, Walker S, Gamble J, Miller M, Wong M, McPhearson A (2000) Mapping consumer perceptions of creaminess and liking for liquid dairy products. Food Quality and Preference 11: 239-246. 